\title{
The Utilization of Magnesium by Certain Gram-Positive and Gram-negative Bacteria
}

\author{
By M. WEBB \\ Strangeways Research Laboratory, Cambridge
}

(Received 2 November 1965)

SUMMARY

Several Gram-positive bacilli and Gram-negative bacteria were found to differ markedly in their ability to concentrate $\mathrm{Mg}^{2+}$ from simple chemically defined media. In cultures of the Gram-negative bacteria the uptake of $\mathrm{Mg}^{2+}$ was quantitative over the range where growth was limited by the concentration of $\mathrm{Mg}^{2+}$. The Gram-positive bacilli, however, were unable to utilize $\mathrm{Mg}^{2+}$ when the external concentration was low, and at higher concentrations sufficient to support about half maximal growth, assimilated less than $\mathbf{5 0} \%$ of the available $\mathrm{Mg}^{2+}$. Both Gramnegative and Gram-positive organisms initially liberated $\mathrm{Mg}^{2+}$ when suspended in $\mathbf{M g}^{2+}$-free media, the $\mathbf{M g}^{2+}$ being re-utilized rapidly by the Gram-negative organisms. In suspensions of Aerobacter aerogenes the liberation of $\mathrm{Mg}^{2+}$ was independent of temperature and the re-utilization of $\mathrm{Mg}^{2+}$ was dependent on temperature.

\section{INTRODUCTION}

Although the magnesium requirements for maximal growth in simple chemically defined media are some ten times greater for Gram-positive bacteria than for Gramnegative bacteria (Webb, 1949a) the magnesium contents of these organisms do not differ greatly (Webb, 1949b; Rouf, 1964), and it is probable that the intracellular concentrations of free cation are similar. De Ley's (1964) observations, for example, on the unity of ribosomes from widely divergent Gram-positive and Gram-negative bacteria, coupled with the known dependence of the structure of polysomes from mammalian, plant and microbial cells on similar concentrations of $\mathrm{Mg}^{2+}$, indicate that the intracellular content of the free cation probably must be maintained within certain critical limits. The present study concerns the utilization of magnesium in bacteria growing in simple media. It is shown that the previously observed variations in the requirements of the Gram-positive and Gram-negative species are due to differences in assimilatory efficiency.

\section{METHODS}

Organisms. Bacillus megaterium (strain $\mathrm{KM}$ ) was obtained from Dr K. McQuillen (Department of Biochemistry, University of Cambridge), Salmonella typhimurium (strain ara 9) from Dr H. E. Umbarger (Long Island Biological Association, Cold Spring Harbor, New York), and Escherichia coli (strain B) from the Department of Molecular Biology, University of Cambridge. Other organisms, the sources of which were given previously (Webb, 1949b), were available from the Strangeways 
Laboratory collection. These were maintained on peptone (British Drug Houses Ltd.) agar (Oxoid Ltd.) slopes, and were transferred at about monthly intervals. Before being used in the $\mathbf{M g}^{2+}$ uptake experiments the organisms were subcultured at least twice in the chemically defined medium with adequate magnesium (10 $\mu \mathrm{g} . / \mathrm{ml}$.) and then once at a low concentration of $\mathrm{Mg}^{2+}$.

Analytical methods. Magnesium was determined by atomic absorption in a PerkinElmer Model 303 Spectrophotometer. Samples of medium for analysis were treated with the appropriate amount of a solution of $\mathrm{La}^{3+}$ in $\mathrm{HCl}$ and diluted with glassdistilled water to contain $0 \cdot 2-2 \cdot 0 \mu \mathrm{g} . \mathrm{Mg}^{2+} / \mathrm{ml}$., $0 \cdot 1 \%$ (w/v) $\mathrm{La}^{3+}$ and $0.06 \mathrm{~N}-\mathrm{HCl}$. Since under these conditions, interference due to the high contents of phosphate and other salts was not suppressed completely, additional standards were prepared from known amounts of a previously analysed aqueous solution of $\mathrm{MgCl}_{2}$ and appropriate dilutions of the 'magnesium-free' chemically defined media. Extrapolation of these curves to zero absorbance also enabled the magnesium content of the basal media to be determined accurately.

The stock solution of $\mathrm{La}^{3+}(5 \%, \mathrm{w} / \mathrm{v})$ in $3 \mathrm{~N}-\mathrm{HCl}$ (AnalaR; British Drug Houses Ltd.) was prepared from lanthanum acetate (Hopkins and Williams Ltd.). All other commercially available soluble lanthanum salts and the oxide which were examined were highly contaminated with magnesium, and gave excessively high reagent blanks.

For the determination of cellular magnesium content, portions of the bacterial suspensions (of known dry weight) were mixed with $25 \%(\mathrm{w} / \mathrm{v})$ trichloroacetic acid $(\mathbf{1} .0 \mathrm{ml}$.) and diluted with glass-distilled water to $\mathbf{5 . 0} \mathrm{ml}$. The bacteria were dispersed with a Whirlimixer (Scientific Industries International Inc. (U.K.) Ltd.) and the suspensions left overnight at room temperature before being centrifuged. Portions of the supernatant solutions after centrifugation were supplemented with $\mathrm{La}^{3+}$ and $\mathrm{HCl}$ as above, and analysed by atomic absorption. Parallel determinations on $\mathrm{H}_{2} \mathrm{SO}_{4}$-digests of suspensions of Aerobacter aerogenes and Escherichia coli were made to confirm that quantitative liberation of $\mathrm{Mg}^{2+}$ was obtained by the TCAextraction procedure.

Culture media and growth conditions. All glassware was cleaned by the methods previously described (Webb, 1949a).

The compositions (g./l.) of the chemically defined media made up in glassdistilled water, were as follows :

Medium M: $\left(\mathrm{NH}_{4}\right)_{2} \mathrm{SO}_{4}, 2 \cdot 75 \mathrm{~g}$; $\mathrm{KH}_{2} \mathrm{PO}_{4}, 3 \cdot 0$ g.; $\mathrm{Na}_{2} \mathrm{HPO}_{4}, 7 \cdot 29$ g.; glucose, $5 \cdot 5 \mathrm{~g}$.

Medium P: $\left(\mathrm{NH}_{4}\right)_{2} \mathrm{SO}_{4}, 2 \cdot 0$ g.; $\mathrm{K}_{2} \mathrm{HPO}_{4}, 14 \cdot 0$ g.; $\mathrm{KH}_{2} \mathrm{PO}_{4} 6 \cdot 0$ g.; sodium citrate dihydrate, $\mathbf{1} \cdot 0 \mathrm{~g}$.; glucose $5 \cdot 0 \mathrm{~g}$.

These solutions were adjusted to $\mathrm{pH} 7 \cdot 0$, supplemented with $\mathrm{FeSO}_{4} 7 \mathrm{H}_{2} \mathrm{O}$ (500 $\mu \mathrm{g}$.), $\mathrm{CaCl}_{2} 2 \mathrm{H}_{2} \mathrm{O}$ (10 mg.) and $\mathrm{Mg}^{2+}$ as indicated in the tables and figures, and sterilized by filtration through sintered glass filters. In some experiments the citrate was omitted from medium $P$.

The glucose used in the preparation of the above media was dissolved in water (1 g. $/ 10 \mathrm{ml}$.) and the solution passed through a column $(10 \mathrm{~cm} . \times 2 \mathrm{~cm}$. diam.) of Chelex 100 analytical grade chelating resin (100-200 mesh; sodium hydrogen form. Bio-Rad Laboratories, Richmond, California, U.S.A.). This procedure was used also to remove bivalent cations from the mixture of amino acids that was added as a supplement to medium $\mathbf{P}$ in one series of experiments with Bacillus megaterium. 
Other chemicals, all of AnalaR grade, were used without additional purification, since the degree of contamination by magnesium was small (less than $0 \cdot 1 \mu \mathrm{g} . / \mathrm{ml}$. of the final medium).

Aerobic cultures were grown in $5 \mathrm{ml}$. volumes of medium in $25 \mathrm{ml}$. Pyrex Erlenmeyer flasks. The flasks were capped with specimen tubes or small beakers and were incubated on a mechanical shaker at $37^{\circ}$. For anaerobic growth, the cultures (10 ml.) were prepared in boiling-tubes plugged with cotton wool enclosed in gauze. Pasteur pipettes were inserted through the plugs into the medium and were connected through a manifold to a source of water-saturated $\left(37^{\circ}\right) 95 \%(\mathrm{v} / \mathrm{v}) \mathrm{N}_{2}+5 \% \mathrm{CO}_{2}$. These cultures were incubated in a water bath at $37^{\circ}$. In each group of experiments, an additional uninoculated series of tubes or flasks was set up, incubated in parallel with the experimental series and then analysed to detect changes in concentration through evaporation.

Inocula $(0 \cdot 1 \mathrm{ml}$.) for experiments with the Gram-negative organisms were taken from fully grown cultures in media that contained initially about $0.5 \mu \mathrm{g} . \mathrm{Mg}^{2+} / \mathrm{ml}$. In these cultures the $\mathrm{Mg}^{2+}$ was utilized completely; the culture fluid contained no residual $\mathrm{Mg}^{2+}$. As shown in the Results section, however, the Gram-positive bacilli not only required higher concentrations of $\mathrm{Mg}^{2+}$ to support growth, but did not assimilate the $\mathrm{Mg}^{2+}$ quantitatively. Thus, with these organisms, additional $\mathrm{Mg}^{2+}$ was transferred to each of the experimental cultures in the inoculum. In some experiments to correct for this, the excess inoculum was centrifuged and the same volume of the supernatant fluid $(0.1 \mathrm{ml}$.) then added to each flask of the uninoculated control series. In others, the primary culture was centrifuged and the organisms resuspended in the same volume of $\mathrm{Mg}^{2+}$-free medium to provide an inoculum of decreased $\mathrm{Mg}^{2+}$ content.

After incubation for $\mathbf{1 6} \mathrm{hr}$ the amount of growth in the experimental series was measured turbidimetrically in a Hilger Spekker Absorptiometer on suitably diluted portions of the cultures, the extinction readings being converted to equivalent dry weight of organism $(\mu \mathrm{g} . / \mathrm{ml}$.) by means of standard curves that were prepared for each of the organisms. The remainder of each culture was centrifuged and the supernatant fluid analysed for $\mathbf{M g}^{2+}$.

\section{RESULTS}

The data of Tables 1, 2, and 3 (left-hand series) and of Figs. 1 and 2 (aerobic cultures) show clearly that the Gram-positive bacilli Bacillus subtilis, (strains F3, Marburg, viscosus), B. mesentericus, $\boldsymbol{B}$. megaterium and the Gram-negative bacteria Aerobacter aerogenes, Escherichia coli, Salmonella typhimurium and Pseudomonas aeruginosa differed greatly in ability to concentrate $\mathrm{Mg}^{2+}$. In aerobic cultures of the Gram-negative bacteria, the uptake of $\mathrm{Mg}^{2+}$ was quantitative at concentrations in the medium of from 0.03 to $1.5-2 \mu \mathrm{g}$. $/ \mathrm{ml}$. Growth, which occurs even at very low concentrations of $\mathrm{Mg}^{2+}$, increased rapidly with concentration over this range. For $\boldsymbol{E}$. coli growth and $\mathbf{M g}^{2+}$-uptake followed similar curves to those shown in Fig. $\mathbf{I}$ for $S$. typhimurium and in Fig. 2 for the aerobic culture of $A$. aerogenes. With these bacteria under the given conditions of cultivation, the $\mathrm{Mg}^{2+}$ requirements seemed to be satisfied when the concentration of $\mathrm{Mg}^{2+}$ in the medium was about $4 \mu \mathrm{g} . / \mathrm{ml}$. Above this concentration, little increase in growth or uptake occurred. In cultures 
of $\boldsymbol{P}$. aeruginosa uptake of $\mathrm{Mg}^{2+}$ continued to increase progressively with increase in external concentration, although maximum growth was reached at about $\mathrm{Mg}^{2+}$ $5 \mu \mathrm{g} . / \mathrm{ml}$.

Table 1. Uptake of $\mathbf{M g}^{2+}$ in cultures of certain Gram-positive and Gram-negative bacteria

The cultures were incubated for $15 \mathrm{hr}$ in medium $\mathbf{P}$ of increasing $\mathbf{M g}^{2+}$ content, as described in the text.

\begin{tabular}{|c|c|c|c|c|c|c|}
\hline $\begin{array}{c}\mathrm{Mg}^{2+} \\
(\mu \mathrm{g} \cdot / \mathrm{ml} .)\end{array}$ & $\begin{array}{l}\text { Growth } \\
\text { ( } \mu \text { g. dry wt. } \\
\text { organism/ } \\
\text { ml. } \\
\text { culture) }\end{array}$ & $\begin{array}{c}\mathrm{Mg}^{2+} \\
\text { uptake } \\
(\%)\end{array}$ & $\begin{array}{c}\text { Growth } \\
\text { ( } \mu \text { g. dry wt. } \\
\text { organism/ } \\
\text { ml. } \\
\text { culture) }\end{array}$ & $\begin{array}{c}\mathbf{M g}^{2+} \\
\text { uptake } \\
(\%)\end{array}$ & $\begin{array}{l}\text { Growth } \\
\text { ( } \mu \text { g. dry wt. } \\
\text { organism/ } \\
\text { ml. } \\
\text { culture) }\end{array}$ & $\begin{array}{c}\mathrm{Mg}^{2+} \\
\text { uptake } \\
(\%)\end{array}$ \\
\hline & \multicolumn{2}{|c|}{ Aerobacter aerogenes } & \multicolumn{2}{|c|}{ Escherichia coli В } & \multicolumn{2}{|c|}{ Bacillus subtilis $\mathbf{F} \mathbf{3}$} \\
\hline 0.09 & 104 & 100 & 64 & 100 & 14 & $\mathbf{0}$ \\
\hline $0 \cdot 48$ & 338 & 100 & $\mathbf{3 1 8}$ & 100 & 18 & $\mathbf{0}$ \\
\hline 0.82 & 658 & 100 & 606 & 100 & 24 & $\mathbf{0}$ \\
\hline $1 \cdot 15$ & 1120 & 100 & 710 & 100 & 60 & $\mathbf{0}$ \\
\hline 1.52 & 1392 & 100 & 838 & 100 & 171 & $10 \cdot 2$ \\
\hline 1.89 & 1600 & $97 \cdot 9$ & 938 & $87 \cdot 5$ & 332 & $20 \cdot 2$ \\
\hline $2 \cdot 93$ & 1630 & $93 \cdot 9$ & 1050 & $82 \cdot 2$ & 366 & $17 \cdot 5$ \\
\hline $\mathbf{8} \cdot 87$ & 1718 & $85 \cdot 0$ & 1096 & $70 \cdot 4$ & 346 & $11 \cdot 9$ \\
\hline $5 \cdot 74$ & 1854 & $60 \cdot 3$ & 1142 & $50 \cdot 8$ & 412 & $11 \cdot 3$ \\
\hline $7 \cdot 61$ & 1848 & $49 \cdot 0$ & 1132 & $42 \cdot 1$ & 428 & 9.7 \\
\hline \multirow[t]{2}{*}{$9 \cdot 49$} & 1742 & $\mathbf{3 8} \cdot \mathbf{3}$ & 1086 & 34.7 & 470 & $7 \cdot 9$ \\
\hline & \multicolumn{2}{|c|}{$\begin{array}{c}\text { Bacillus subtilis } \\
\text { Marburg }\end{array}$} & \multicolumn{2}{|c|}{ Bacillus mesentericus } & \multicolumn{2}{|c|}{$\begin{array}{c}\text { Salmonella } \\
\text { typhimurium ara } 9\end{array}$} \\
\hline 0.03 & 15 & o & 30 & 0 & 92 & 100 \\
\hline $0 \cdot 35$ & 15 & 0 & 27 & o & 318 & 100 \\
\hline 0.73 & 14 & 0 & 40 & o & 552 & 100 \\
\hline 1.03 & 51 & $18 \cdot 2$ & 54 & o & 648 & 100 \\
\hline 1.47 & 417 & $48 \cdot 8$ & 70 & 0 & 758 & 100 \\
\hline 1.85 & 520 & $48 \cdot 9$ & 190 & $3 \cdot 8$ & 1008 & 100 \\
\hline $2 \cdot 79$ & 648 & 48.9 & 880 & $38 \cdot 8$ & 1018 & $68 \cdot 6$ \\
\hline 3.76 & 672 & $38 \cdot 4$ & 890 & $35 \cdot 4$ & 1018 & $61 \cdot 2$ \\
\hline $5 \cdot 67$ & 678 & $27 \cdot 0$ & 920 & $27 \cdot 8$ & 1048 & 42.9 \\
\hline $7 \cdot 56$ & 690 & $21 \cdot 2$ & 1000 & $25 \cdot 2$ & 1268 & $34 \cdot 5$ \\
\hline 9.52 & 694 & $15 \cdot 4$ & - & $\longrightarrow$ & 908 & 24.5 \\
\hline
\end{tabular}

At low $\mathrm{Mg}^{2+}$ concentrations complete uptake of the cation in cultures of Aerobacter aerogenes occurred both anaerobically and aerobically (Fig. 2). Although the maximum growth supported by the medium under anaerobic conditions was less than under aerobic conditions, the ratio of $\mathrm{Mg}^{2+}$ concentration to dry weight of organism at the points where $\mathrm{Mg}^{2+}$ uptake ceased to be complete were essentially the same.

In contrast to the Gram-negative organisms, the Gram-positive bacilli seemed unable to utilize $\mathrm{Mg}^{2+}$ when the concentration was less than $4 \times 10^{-5} \mathrm{M}$, and for Bacillus megaterium an even higher concentration was necessary for growth. Below this minimum value, not only did the organisms not grow, but they liberated $\mathbf{M g}^{2+}$ (Tables 2 and 3). Once the critical concentration of $\mathbf{M g}^{2+}$ was exceeded, growth of the Gram-positive bacilli increased, at first rapidly and then more slowly, with further increases in $\mathrm{Mg}^{2+}$ concentration, the requirements for maximum growth (Table 2) being much greater than for the Gram-negative bacteria. Even over the initial part of this range the uptake of $\mathrm{Mg}^{2+}$ was not quantitative (Table 1 ; Fig. 1). 
In cultures of $B$. megaterium, B. mesentericus and $B$. subtilis strain $\mathrm{F} 3$, all of which grew in solution $\mathbf{P}$ in the absence of sodium citrate, the omission of this component from the medium did not influence either growth or the utilization of $\mathrm{Mg}^{2+}$. In the experiments summarized in Table 1 , therefore, there was no restriction of $\mathrm{Mg}^{2+}$ uptake through chelation of the cation by citrate.

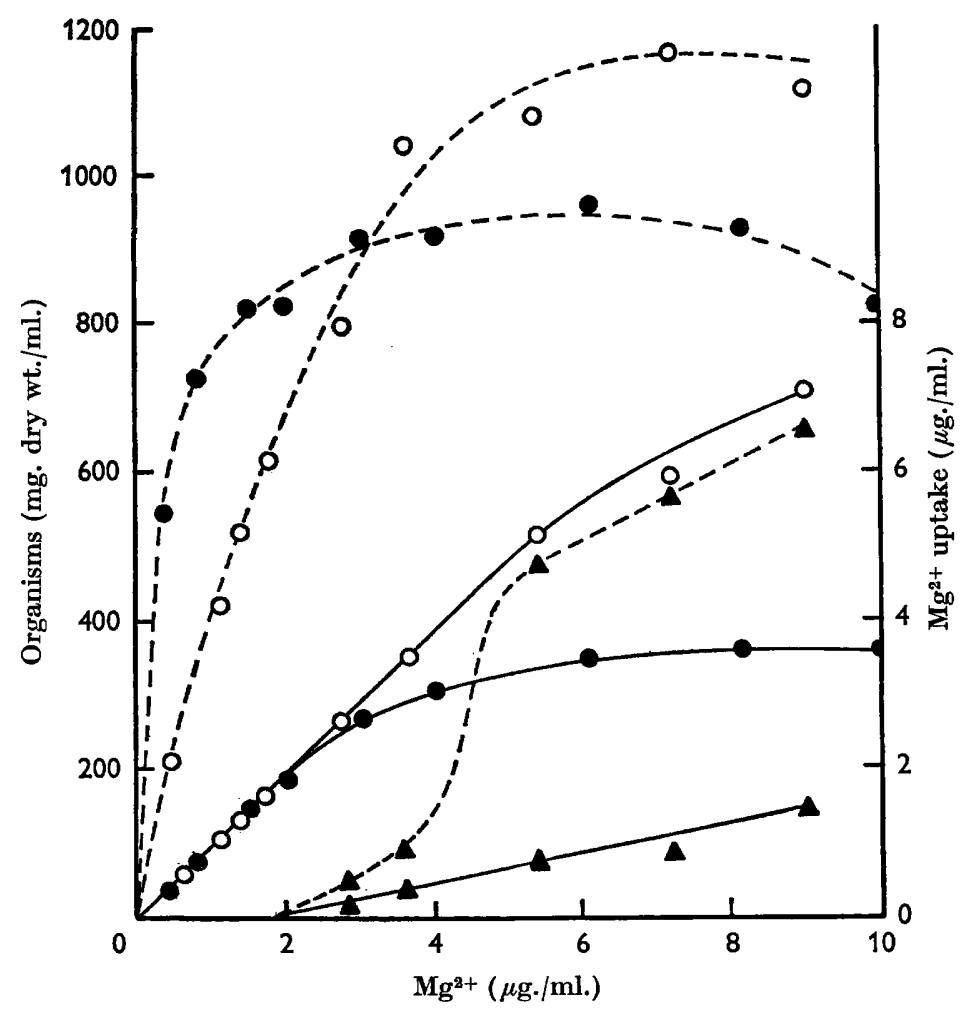

Fig. 1. Growth (dashed lines) and magnesium utilization (solid lines) in relation to the $\mathrm{Mg}^{2+}$ concentration for cultures of Salmonella typhimurium (O) in medium M; of Pseudomonas aeruginosa $(O)$ and Bacillus subtilis strain viscosus $(\boldsymbol{A})$ in medium $\mathbf{P}$.

The data of Table 3 show that after the addition of L-lysine $+\mathrm{L}$-glutamic acid $+\mathrm{L}-$ alanine $+\mathrm{L}$-arginine + DL-tryptophan to the simple basal medium, not only was the $\mathrm{Mg}^{2+}$-uptake by Bacillus megaterium increased, but also both growth and uptake began at a lower external concentration of $\mathrm{Mg}^{2+}$. These results support previous findings that the $\mathrm{Mg}^{2+}$ requirements for maximum growth of several Gram-positive bacilli in simple chemically defined media are decreased by the addition of various amino acid mixtures (Webb, 1951). The presence of several amino acids appeared to be necessary before this decrease took place; no single amino acid was found to be essential.

The liberation of cellular $\mathrm{Mg}^{2+}$ that was observed on transfer of inocula of Grampositive bacilli to a $\mathbf{M g}^{2+-d e f i c i e n t ~ m e d i u m, ~ a l s o ~ o c c u r r e d ~ w i t h ~ G r a m-n e g a t i v e ~}$ bacteria, but with these latter organisms the liberated cation was re-utilized rapidly. Thus when Escherichia coli and Bacillus megaterium were grown in the 
presence of $\mathrm{Mg}^{2+} 10 \mu \mathrm{g} . / \mathrm{ml}$. and then resuspended at $37^{\circ}$ in media deficient with respect to $\mathrm{Mg}^{2+}$, both organisms liberated about $20 \%$ of their $\mathrm{Mg}^{2+}$ (Table 4). On further incubation of the suspensions of $\boldsymbol{E}$. coli the liberated $\mathrm{Mg}^{2+}$ was re-assimilated rapidly, and when the initial suspension concentration was low, some grow th occurred

\section{Table 2. Growth and $\mathbf{M g}^{2+}$ uptake in cultures of Bacillus subtilis and}

$B$. mesentericus in relation to the magnesium content of the medium

The inocula for these cultures were grown in the chemically defined medium $\mathbf{P}$ containing $\mathrm{Mg}^{2+} 5 \mu \mathrm{g}$. $/ \mathrm{ml}$. The bacteria were separated by centrifugation after $18 \mathrm{hr}$ and resuspended in the same volumes of $\mathrm{Mg}^{2+}$-free medium. Each experimental flask was inoculated with $0.1 \mathrm{ml}$. of the appropriate suspension, and incubated for $16 \mathrm{hr}$ at $37^{\circ}$.

\begin{tabular}{|c|c|c|c|c|c|}
\hline \multicolumn{3}{|c|}{ Bacillus subtilis $\mathbf{F} 3$} & \multicolumn{3}{|c|}{ Bacillus mesentericus } \\
\hline $\begin{array}{c}\mathrm{Mg}^{2+} \\
(\mu \mathrm{g} \cdot / \mathrm{ml} .)\end{array}$ & $\begin{array}{c}\text { Growth ( } \mu \mathrm{g} . \\
\text { dry weight } \\
\text { organism } / \mathrm{ml} \text {. } \\
\text { culture) }\end{array}$ & $\begin{array}{c}\mathrm{Mg}^{2+} \\
\text { uptake } \\
(\%)\end{array}$ & $\begin{array}{c}\mathbf{M g}^{2+} \\
(\mu \mathrm{g} . / \mathrm{ml} .)\end{array}$ & $\begin{array}{c}\text { Growth ( } \mu \text { g. } \\
\text { dry weight } \\
\text { organism/ml. } \\
\text { culture) }\end{array}$ & $\begin{array}{c}\mathrm{Mg}^{2+} \\
\text { uptake } \\
(\%)\end{array}$ \\
\hline 0.03 & 6 & 0* & 0.08 & $\mathbf{5}$ & $0^{*}$ \\
\hline $9 \cdot 3$ & 720 & $15 \cdot 3$ & $1 \cdot 88$ & $\mathbf{3 4}$ & 3.9 \\
\hline $18 \cdot 9$ & 732 & $9 \cdot 8$ & $\mathbf{3} \cdot 86$ & 1075 & $\mathbf{3 7} \cdot \mathbf{3}$ \\
\hline $28 \cdot 9$ & 754 & $\mathbf{8} \cdot \mathbf{3}$ & $5 \cdot 87$ & 1280 & $45 \cdot 8$ \\
\hline $38 \cdot 1$ & 756 & $7 \cdot 5$ & $7 \cdot 58$ & 1510 & $26 \cdot 7$ \\
\hline $47 \cdot 8$ & 740 & $6 \cdot 4$ & $9 \cdot 68$ & $\mathbf{1 5 0 0}$ & 30.2 \\
\hline $57 \cdot 3$ & 696 & $5 \cdot 7$ & $16 \cdot 1$ & 1520 & $12 \cdot 1$ \\
\hline $67 \cdot 0$ & 672 & $5 \cdot 1$ & $21 \cdot 0$ & 1420 & $9 \cdot 3$ \\
\hline 76.7 & 674 & $5 \cdot 4$ & $31 \cdot 4$ & 1400 & $10 \cdot 0$ \\
\hline $86 \cdot 4$ & 644 & $5 \cdot 7$ & $41 \cdot 0$ & 940 & $5 \cdot 1$ \\
\hline
\end{tabular}

* In both of these cultures the magnesium content was greater than in the corresponding, uninoculated control. The liberated $\mathrm{Mg}^{2+}$ amounted to $0.048 \mu \mathrm{g} . / \mathrm{ml}$. and $0.082 \mu \mathrm{g} . / \mathrm{ml}$. in the $B$. subtilis and $\boldsymbol{B}$. mesentericus cultures, respectively.

Table 3. Influence of an amino acid supplement on the growth and magnesiumutilization of Bacillus megaterium $\mathrm{KM}$ in a mineral salts glucose medium

Measurements were made on both cultures after incubation for $16 \mathrm{hr}$ at $37^{\circ}$.

Basal medium $\mathbf{P}$

\begin{tabular}{|c|c|c|c|c|c|c|c|}
\hline \multirow{2}{*}{$\begin{array}{c}\mathbf{M g}^{2+} \\
(\mu \mathrm{g} \cdot / \mathrm{ml} .)\end{array}$} & \multirow{2}{*}{$\begin{array}{l}\text { Growth } \\
\text { ( } \mu \mathrm{g} \text {. dry wt. } \\
\text { organism/ } \\
\text { ml. } \\
\text { culture) }\end{array}$} & \multicolumn{2}{|c|}{$\begin{array}{l}\mathrm{Mg}^{2+} \text { uptake or } \\
\text { liberation }\end{array}$} & \multirow{2}{*}{$\begin{array}{c}\mathbf{M g}^{2+} \\
(\mu \mathrm{g} . / \mathrm{ml} .)\end{array}$} & \multirow{2}{*}{$\begin{array}{l}\text { Growth } \\
\text { ( } \mu \text { g. dry wt. } \\
\text { organism/ } \\
\text { ml. } \\
\text { culture) }\end{array}$} & \multicolumn{2}{|c|}{$\begin{array}{c}\mathrm{Mg}^{2+} \text { uptake or } \\
\text { liberation }\end{array}$} \\
\hline & & $(\mu \mathrm{g} . / \mathrm{ml})$. & $(\%)$ & & & $(\mu \mathrm{g} . / \mathrm{ml})$. & $(\%)$ \\
\hline 0.03 & 24 & $+0.14 \dagger$ & 0 & 0.05 & $9 \cdot 6$ & +0.08 & $\mathbf{0}$ \\
\hline $0 \cdot 35$ & 24 & +0.21 & 0 & $0 \cdot 38$ & $9 \cdot 6$ & $+0 \cdot 16$ & $\mathbf{0}$ \\
\hline 0.73 & 26 & +0.26 & 0 & $0 \cdot 75$ & $9 \cdot 6$ & $+0 \cdot 10$ & 0 \\
\hline 1.03 & 31 & +0.14 & 0 & $1 \cdot 13$ & 16 & $+0 \cdot 10$ & 0 \\
\hline 1.47 & 31 & +0.08 & $\mathbf{0}$ & $1 \cdot 50$ & 18 & 0.03 & $2 \cdot 0$ \\
\hline $1 \cdot 85$ & 35 & +0.03 & 0 & $1 \cdot 87$ & 282 & 0.50 & $26 \cdot 8$ \\
\hline $2 \cdot 79$ & 50 & +0.04 & 0 & $2 \cdot 82$ & 1880 & $1 \cdot 07$ & $38 \cdot 0$ \\
\hline $3 \cdot 76$ & 76 & +0.05 & 0 & $3 \cdot 75$ & 2032 & $2 \cdot 07$ & $55 \cdot 2$ \\
\hline $5 \cdot 67$ & 1010 & $1 \cdot 15$ & $20 \cdot 3$ & - & - & - & - \\
\hline $7 \cdot 56$ & 1040 & 1.71 & $22 \cdot 6$ & - & - & - & $\ldots$ \\
\hline 9.52 & 1060 & $2 \cdot 04$ & $21 \cdot 4$ & - & - & - & - \\
\hline
\end{tabular}

Basal medium + supplementary amino acids* 
(Table 4). With $B$, megaterium under these conditions there was partial re-utilization of the $\mathrm{Mg}^{2+}$ in the first $20 \mathrm{~min}$. of incubation, but thereafter, presumably as a result of autolysis, even greater amounts of the $\mathrm{Mg}^{2+}$ were liberated and the bacterial mass decreased. The initial re-utilization and subsequent liberation of $\mathrm{Mg}^{2+}$ were, respectively, greater and less at high (equiv. $2 \mathrm{mg}$. dry wt. organism/ml.) than at low (equiv. $\mathbf{0 . 5} \mathrm{mg}$. dry wt./ml.) suspension concentrations (Table 4).

\section{Table 4. Magnesium liberation from Escherichia coli (Gram-negative) and from Bacillus megaterium (Gram-positive)}

Cultures of E. coli and B. megaterium in medium $\mathrm{M}\left(400 \mathrm{ml}\right.$.; $\mathrm{Mg}^{2+} 10 \mu \mathrm{g} . / \mathrm{ml}$.) and medium $\mathrm{P}\left(400 \mathrm{ml}\right.$.; $\mathrm{Mg}^{2+} 10 \mu \mathrm{g} . / \mathrm{ml}$.), respectively, were grown with shaking at $37^{\circ}$, and harvested after $11 \mathrm{hr}\left(\mathrm{Mg}^{2+}\right.$ uptake in $\boldsymbol{E}$. coli culture $=2 \cdot 24 \mu \mathrm{g} . / \mathrm{ml}$; in $B$. megaterium culture $=1.08 \mu \mathrm{g} . / \mathrm{ml}$.) The organisms were washed twice with $0.9 \% \mathrm{NaCl}$ (total vol. $150 \mathrm{ml}$; $\mathrm{Mg}^{2+}$ contents of washings from $E$. coli and $B$. megaterium were 0.99 and $0.47 \mu \mathrm{g} . / \mathrm{ml}$,, respectively) and resuspended in $0.9 \% \mathrm{NaCl}$ at about equiv. $50 \mathrm{mg}$. dry wt. organism/ml. Both suspensions, which contained $1.40\left(E\right.$. coli) and $1.03\left(B\right.$. megaterium) $\mathrm{Mg}^{2+} \mu \mathrm{g} . / \mathrm{mg}$. dry wt. organisms, were diluted with the appropriate $\mathrm{Mg}^{2+}$-free medium, prewarmed to $37^{\circ}$, and incubated with shaking at this temperature. Immediately after preparation, and at intervals thereafter, samples of the suspensions were removed, cooled in crushed ice and centrifuged, the supernatant fractions being analysed for $\mathrm{Mg}^{2+}$. Dry weights were determined turbidimetrically on other portions of the suspensions after dilution.

Initial suspension concentration (mg. dry wt. organism/ml.)

\begin{tabular}{|c|c|c|c|c|c|c|}
\hline \multirow{3}{*}{$\begin{array}{c}\text { Period } \\
\text { of } \\
\text { incubation } \\
(\mathrm{hr}) \\
\text { at } \mathbf{3} 7^{\circ}\end{array}$} & \multicolumn{3}{|c|}{0.5} & \multicolumn{3}{|c|}{$\mathbf{2 \cdot 0}$} \\
\hline & \multirow{2}{*}{$\begin{array}{c}\text { Suspension } \\
\text { concen- } \\
\text { tration* }\end{array}$} & \multicolumn{2}{|c|}{$\mathrm{Mg}^{2+}$ leakage } & \multirow{2}{*}{$\begin{array}{l}\text { Suspension } \\
\text { concen- } \\
\text { tion* }\end{array}$} & \multicolumn{2}{|c|}{$\mathrm{Mg}^{2+}$ leakage } \\
\hline & & $\mu \mathrm{g} . / \mathrm{ml}$ & $\begin{array}{c}\% \text { of } \\
\text { total } \mathbf{M g}^{2+}\end{array}$ & & $\mu \mathrm{g} . / \mathrm{ml}$ & $\begin{array}{c}\% \text { of } \\
\text { total } \mathrm{Mg}^{2+}\end{array}$ \\
\hline \multicolumn{7}{|c|}{ Escherichia coli } \\
\hline $\mathbf{0}$ & 476 & $0 \cdot 136$ & $20 \cdot 4$ & 1960 & $0 \cdot 56$ & $19 \cdot 7$ \\
\hline $\mathbf{0 \cdot 3 3}$ & 一 & $0 \cdot 052$ & $7 \cdot 8$ & - & 0.06 & $2 \cdot 2$ \\
\hline $2 \cdot 2$ & 772 & $0 \cdot 0$ & $0 \cdot 0$ & 1820 & $0 \cdot 0$ & 0.0 \\
\hline $4 \cdot 2$ & 900 & 0.0 & 0.0 & 1880 & $0 \cdot 0$ & 0.0 \\
\hline $6 \cdot 0 \dagger$ & - & $\mathbf{0 \cdot 0}$ & $0 \cdot 0$ & 一 & $0 \cdot 0$ & $0 \cdot 0$ \\
\hline \multicolumn{7}{|c|}{ Bacillus megaterium } \\
\hline $\mathbf{0}$ & 436 & $0 \cdot 14$ & $31 \cdot 2$ & 1880 & $0 \cdot 36$ & $18 \cdot 6$ \\
\hline $0 \cdot 33$ & - & $0 \cdot 10$ & $22 \cdot 2$ & - & $0 \cdot 26$ & $13 \cdot 5$ \\
\hline $2 \cdot 2$ & 428 & $0 \cdot 20$ & $44 \cdot 6$ & 1640 & $0 \cdot 20$ & $10 \cdot 4$ \\
\hline $4 \cdot 2$ & 404 & 0.28 & $62 \cdot 4$ & 1620 & 0.28 & $14 \cdot 5$ \\
\hline $6 \cdot 0 \dagger$ & 一 & $0 \cdot 39$ & $86 \cdot 9$ & 一 & $0 \cdot 56$ & $29 \cdot 0$ \\
\hline
\end{tabular}

* Equiv. $\mu \mathrm{g}$. dry wt. organism/ml.

$\dagger$ At this time only intact normal rods were present in the $E$. coli suspensions, whereas the suspensions of $B$. megaterium contained much debris and many very swollen organisms.

As shown by Fig. 3, the liberation of $\mathrm{Mg}^{2+}$ from Aerobacter aerogenes in a $\mathrm{Mg}^{2+}$ free medium seemed to occur by diffusion, whereas the re-utilization of $\mathrm{Mg}^{2+}$ was an energy-dependent process. Thus, about the same amounts of $\mathbf{M g}^{2+}$ was liberated from suspensions of equal dry weight at $0^{\circ}, 10^{\circ}, 20^{\circ}$ and $30^{\circ}$. The rate of re-utilization $\left(\mathrm{Mg}^{2+} \mu \mathrm{g}\right.$. $/ \mathrm{hr} / \mathrm{mg}$. dry wt. organism) which, under the defined experimental conditions, was essentially zero at $0^{\circ}$, increased with temperature, and was $1 \cdot 10$ at $10^{\circ}, 2 \cdot 16$ at $20^{\circ}$, and, with reservations because of the extrapolation, $5 \cdot 32$ at $30^{\circ}$. 


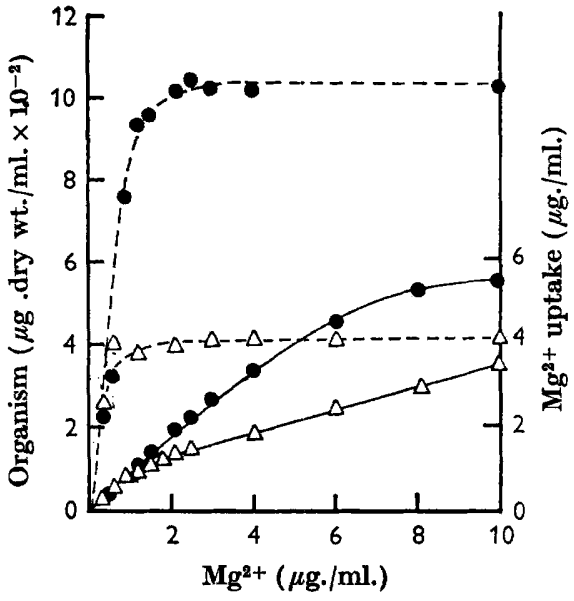

Fig. 2

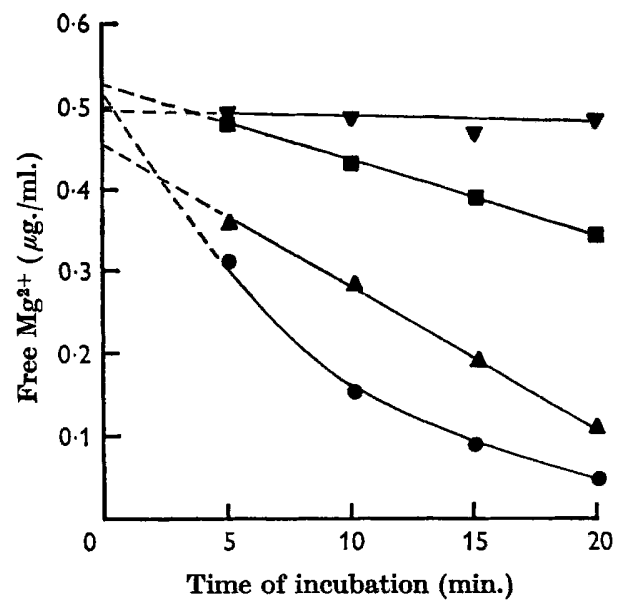

Fig. 3

Fig. 2. Growth (dashed lines) and magnesium utilization (solid lines) in relation to the $\mathrm{Mg}^{2+}$ concentration in aerobic $(O)$ and anaerobic $(\Delta)$ cultures of Aerobacter aerogenes in medium $\mathbf{M}$.

Fig. 3. $\mathrm{Mg}^{2}+$ liberation from, and re-utilization by Aerobacter aerogenes when suspended with a metabolizable substrate in the absence of exogenous $\mathrm{Mg}^{2+}$ at $\mathrm{pH} 6 \cdot 0$, at $0^{\circ}(\nabla)$, $10^{\circ}(\square), 20^{\circ}(\Delta), 30^{\circ}(O)$. For these measurements, mixtures of $0.1 \mathrm{M}$-potassium phosphate buffer (pH 6.0;7.5 ml.), 0.04 $\mathrm{M}-\mathrm{Na}$ pyruvate $(2.5 \mathrm{ml}$.) and water $(5.0 \mathrm{ml}$.) were brought to the above temperatures, and a suspension of $A$. aerogenes $(5 \cdot 0 \mathrm{ml}$.; equiv. 10 mg. dry wt. organism $/ \mathrm{ml}$. in $0.9 \%, \mathrm{w} / \mathrm{v}, \mathrm{NaCl}$ ) added to each. The suspensions were incubated with shaking for 20 min., portions of each being withdrawn at 5 min. intervals, cooled rapidly to $0^{\circ}$ and centrifuged. Magnesium was determined in the supernatant solutions as described in Methods section.

\section{DISCUSSION}

The preceding results show that the Gram-positive bacilli were unable to utilize $\mathrm{Mg}^{2+}$ when the concentration of this ion was low in a simple medium, otherwise adequate for growth. In media of increasing $\mathrm{Mg}^{2+}$ content, the onset of growth was correlated with $\mathrm{Mg}^{2+}$ uptake, but the concentration at which assimilation began seemed to vary with the species (Table 1 ). Even when the $\mathrm{Mg}^{2+}$ concentration was sufficient to support half-maximal growth, less than $50 \%$ of the available $\mathrm{Mg}^{2+}$ was assimilated. In contrast, the uptake of $\mathrm{Mg}^{2+}$ in cultures of all the Gram-negative bacteria examined was quantitative over the range where growth was limited by the $\mathrm{Mg}^{2+}$ concentration, and even when this concentration was extremely low, some increase in dry weight of organisms occurred (Table 1). These observations on cultures of Gram-negative bacteria support and extend to other organisms the findings of Tempest, Hunter \& Sykes (1965) about the $\mathrm{Mg}^{2+}$-limited growth of Aerobacter aerogenes.

Both Gram-negative bacteria and Gram-positive bacteria liberated $\mathbf{M g}^{2+}$, apparently by diffusion, when suspended in media free from this cation (Table 4). The Gram-negative bacteria, however, rapidly re-utilized the liberated $\mathbf{M g}^{2+}$, whereas with the Gram-positive bacilli, assimilation was incomplete, and ultimately the cellular structure disintegrated. Re-utilization required a metabolizable substrate, which may be either endogenous (unpublished work) or exogeneous (Fig. 3), 
but no other components of the growth medium. The action of various metabolic inhibitors on this energy-dependent utilization of $\mathrm{Mg}^{2+}$, both alone and in relation to the uptake of toxic bivalent heavy metals, will be described subsequently.

The findings discussed above account for the difference between the $\mathrm{Mg}^{2+}$ requirements of Gram-positive bacteria and those of Gram-negative bacteria for growth in simple chemically defined media (Webb, 1949 $a$ ). They also suggest that the effects of $\mathrm{Mg}^{2+}$ deficiency on the structure and function of the ribosomal aggregates may be more pronounced in the Gram-positive organisms than in the Gramnegative ones. This would explain previous observations (Webb, 1953) on the decrease in protein content of Gram-positive but not Gram-negative bacteria during growth in $\mathbf{M g}^{2+}$-deficient media.

Thus far, studies on the effects of $\mathbf{M g}^{2+}$ deficiency on the ribosomal structures of bacteria appear to have been confined to Gram-negative organisms. Kennell \& Magasanik (1962), for example, observed that $\mathrm{Mg}^{2+}$ starvation greatly decreased the ribosome content of an arginine- and guanine-requiring mutant of Aerobacter aerogenes. Also, McCarthy (1962) found that log-phase Escherichia coli cells remained viable when incubated for $20 \mathrm{hr}$ in a medium without $\mathrm{Mg}^{2+}$, but show an almost complete loss of ribosomes, and even after $6 \mathrm{hr}$ there was a considerable decrease in the content of $70 \mathrm{~S}$ particles. In this connexion it is interesting that the results of Table 4 show that, after the re-utilization of the $\mathrm{Mg}^{2+}$ initially liberated from $A$. aerogenes on transfer to the $\mathrm{Mg}^{2+}$ deficient medium, there was no further loss of the cation over a $6 \mathrm{hr}$ period. As the integrity of ribosomes depends not only upon the concentration of $\mathrm{Mg}^{2+}$, but also on the relative concentrations of other ions, particularly $\mathrm{K}^{+}$and $\mathrm{Na}^{+}$(e.g. Elson, 1961) it seems possible, therefore, that the disappearance of these structures from Gram-negative cells in response to $\mathrm{Mg}^{2+}$ deficiency may be due to the unfavourable intracellular ratio of monovalent cations to $\mathrm{Mg}^{2+}$, rather than to the loss of $\mathrm{Mg}^{2+}$ from the organisms.

The skilled technical assistance of Miss C. A. Custerson is gratefully acknowledged.

\section{REFERENCES}

DE LEy, J. (1964). On the unity of bacterial ribosomes. J. gen. Microbiol. 34, 219.

Elson, D. (1961). A ribonucleic acid particle released from ribosomes by salt. Biochim. biophys. Acta, 53, 232.

Kenneld, D. \& Magasanik, B. (1962). The relation of ribosome content to the rate of enzyme synthesis in Aerobacter aerogenes. Biochim. biophys. Acta, 55, 139.

McCARTHY, B. J. (1962). The effects of magnesium starvation on the ribosome content of Escherichia coli. Biochim. biophys. Acta, 55, 880.

Rouf, M. A. (1964). Spectrochemical analysis of inorganic elements in bacteria. J. Bact. 88, 1545.

Tempest, D. W., Hunter, J. R. \& Sykes, J. (1965). Magnesium-limited growth of Aerobacter aerogenes in a chemostat. J. gen. Microbiol. 39, 355.

WEBв, M. (1949 $a)$. The influence of magnesium on cell division. 3. The effect of magnesium on the growth of bacteria in simple chemically-defined media. J. gen. Microbiol. 3, 418.

Webв, M. $(1949 b)$. The influence of magnesium on cell division. 2. The effect of magnesium on the growth and cell division of various bacterial species in complex media. J. gen. Microbiol. 3, 410.

Webs, M. (1951). The influence of magnesium on cell division. 5. The effect of magnesium on the growth of bacteria in chemically defined media of varying complexity. J. gen. Microbiol. 5, 485.

WEBB, M. (1953). Effects of magnesium on cellular division in bacteria. Science, 118, 607. 